\title{
In vitro production of conidia of Alternaria solani
}

\author{
Tatiana T.M.S. Rodrigues, Luiz A. Maffia, Onkar D. Dhingra \& Eduardo S.G. Mizubuti \\ Departamento de Fitopatologia, Universidade Federal de Viçosa, 36570-000, Viçosa, MG, Brazil \\ Author for correspondence: Eduardo S.G. Mizubuti, e-mail: mizubuti@ufv.br
}

\begin{abstract}
Sporulation of Alternaria solani can be scarce and is often reduced when the fungus is cultivated in vitro. A series of experiments were conducted to assess the effects of moisture, mycelial wounding, light quality and photoperiod, and culture media on conidial production. A procedure to induce sporulation based on mycelial wounding and dehydration was adapted and validated. Best results were obtained when fungal colonies were grown in $\mathrm{V} 8$ medium at $25^{\circ} \mathrm{C}$ in the dark with agitation for seven days; the mycelium mass was ground, poured into potato dextrose agar ( $\mathrm{pH} \mathrm{6.5)} \mathrm{in} \mathrm{plates,} \mathrm{and} \mathrm{incubated} \mathrm{at} 25 \pm 2^{\circ} \mathrm{C}$ under near ultraviolet light and $12 \mathrm{~h}$-photoperiod. The procedure was validated with 30 isolates of $A$. solani from different hosts, sampling locations, ages, and storage conditions. Conidial production, germination, and infectivity were quantified. Seventy-five percent of the isolates sporulated and the lowest germination rate was $68 \%$. Inoculations of conidial suspension of all isolates resulted in lesions on tomato and potato plants. The effect of subculturing on $A$. solani sporulation was also assessed. After six subcultures, every seven days, there was no reduction in sporulation of colonies that were induced with the protocol.
\end{abstract}

Key words: early blight, biphasic technique, subculture, infection frequency.

\section{RESUMO}

Produção in vitro de conídios de Alternaria solani

A esporulação de Alternaria solani in vitro pode ser escassa e tende a reduzir após sucessivas repicagens. Conduziram-se vários experimentos para avaliar o efeito da umidade, injúria da colônia, qualidade de luz e fotoperíodo, bem como do meio de cultura na produção de conídios. Adaptou-se a técnica bifásica para induzir esporulação, por meio de injúria de micélio e desidratação do meio de cultura. Obtiveram-se melhores resultados quando colônias cresceram em meio V8 a $25^{\circ} \mathrm{C}$, no escuro, sob agitação durante sete dias; a massa de micélio foi triturada e a suspensão depositada em meio BDA (pH 6,5) em placas de Petri, incubando-se a $25 \pm 2^{\circ} \mathrm{C}$, sob luz negra com $12 \mathrm{~h}$ de fotoperíodo. Validou-se o protocolo para 30 isolados de $A$. solani distintos quanto ao hospedeiro, local de origem, idade e forma de armazenamento. Quantificaram-se a produção, germinação e infectividade de conídios. Dos 30 isolados, 75\% esporularam e a germinação mínima de conídios foi de $68 \%$. Todos os isolados foram patogênicos em seus respectivos hospedeiros. Avaliou-se, também, o efeito de repicagens sucessivas na esporulação. Todos os isolados produziram conídios após seis repicagens sucessivas.

Palavras chave: pinta preta, técnica bifásica, subcultura, frequência de infecção.

\section{INTRODUCTION}

In vitro experiments are routinely used to study the nature and control of plant diseases caused by fungal pathogens. Sporulation is a key component for several purposes because fungal spores are frequently used as propagules to infect plants. In the case of potato (Solanum tuberosum L.) and tomato (Solanum lycopersicum L.) early blight, caused by Alternaria solani Sorauer, conidial suspensions are commonly used as inoculum, but sporulation in vitro can be scarce (Rotem, 1994). It is well known that in vitro sporulation of $A$. solani requires special conditions and that conidial production tends to decrease after periodic subculturing of the pathogen (Rotem, 1994).

Considerable attention has been directed towards improving conidial production of Alternaria species by using unfavorable conditions for vegetative growth (Rotem \& Bashi, 1969; Shahin \& Shepard, 1979; Walker, 1980; Ávila et al., 2000; Vieira, 2004). Three major factors that influence sporulation in vitro are commonly manipulated: nutrition, light spectrum, and temperature. Natural culture media are suitable for sporulation, storage, and to maintain viability of the colony after subcultures (Dhingra \& Sinclair, 1995). For instance, the V8 juice medium, PDA (potatodextrose-agar) and media with parts or extracts of plants are used in protocols to induce sporulation of Alternaria spp. (Miller, 1955; Shahin \& Shepard, 1979; Dalla Pria et al., 1997; Ávila et al., 2000; Vieira, 2004). Commonly, calcium carbonate $\left(\mathrm{CaCO}_{3}\right)$ is also added to increase sporulation (Miller, 1955; Shahin \& Shepard, 1979), but it is unknown whether its effect is due to the change in $\mathrm{pH}$ or due to calcium supplementation.

Light and temperature affect many aspects of fungal development, including the formation of reproductive structures. In vitro sporulation of $A$. solani is favored by incubation under continuous fluorescent light $(\lambda=380$ $-775 \eta \mathrm{m}$ ) at $25^{\circ} \mathrm{C}$ or $16 \mathrm{~h}$ photoperiod at $20^{\circ} \mathrm{C}$ (Douglas, 1972) and under black light (near ultraviolet $-\mathrm{NUV}, \lambda=320$ $-400 \mathrm{\eta m}$ ) and $12 \mathrm{~h}$ photoperiod at $25^{\circ} \mathrm{C}$ (Fourtouni et al., 1998). However, the spectrum of fluorescent light contains 
inhibitory wavelengths, especially the blue wavelengths (Honda \& Nemoto, 1984). Fungal sporulation can be either inhibited or stimulated by photoreceptors (Idnurm \& Heitman, 2005). In Neurospora crassa there are at least five photoreceptor groups, which are related to many aspects of the fungus life cycle, including sporulation (Purschwitza et al., 2006).

The factors described above and stress conditions can be properly combined to induce fungal sporulation. Mycelial injury (wounding) and gradual loss of the culture media moisture content lead to stress conditions that stimulate sporulation in Alternaria spp., as found with A. macrospora (Walker, 1980), A. cassiae (Walker, 1982; Ávila et al., 2000; Pitelli \& Amorim, 2003), and A. euphorbiicola (Vieira, 2004). In his pioneering work, Walker (1980) described the biphasic technique for massive production of conidia of $A$. macrospora. The technique is called biphasic because initially the mycelium is produced in liquid medium, wounded, and then transferred to a solid medium to allow sporulation. Little information is available about the mechanism that triggers the production of reproductive structures induced by dehydration and wounding.

Although many studies were conducted to investigate sporulation of $A$. solani in vitro, in general the results vary and the viability and infectivity of conidia taken from colonies induced to sporulate were not measured. Another problem related to these studies is the low number of isolates assessed. Usually, only a single isolate is used to determine the favorable conditions to allow in vitro sporulation. This can be an important issue for highly variable species such as A. solani. Therefore, the objective of the present study was to adapt the protocol developed by Walker (1980) to induce sporulation in A. solani, combining the effects of mycelial wounding, loss of culture media moisture, sources of light, photoperiod, culture medium, and subculturing. Additionally, the protocol developed was validated with several isolates of the pathogen.

\section{MATERIALS AND METHODS}

\section{Isolates, cultural conditions, and conidia quantification}

Thirty different isolates of $A$. solani were used in the experiments (Table 1). Isolates preserved on filter paper were used in all tests to adapt the protocol and to assess the effect of subculturing on conidial production. Mycelial disks of monosporic colonies grown in PDA (200 g of potato, $20 \mathrm{~g}$ of dextrose, $16 \mathrm{~g}$ of agar, $1 \mathrm{~L}$ of distilled waterDW) were transferred to Petri plates with PDA covered with sterilized pieces of filter paper $(1 \times 1 \mathrm{~cm})$ (Dhingra \& Sinclair, 1995). In all experiments, incubation was at $25^{\circ} \mathrm{C}$. After full development of the colonies, the pieces of colonized filter paper were removed and stored in paper envelopes at $-80^{\circ} \mathrm{C}$. Two fragments of colonized filter paper were transferred to Erlenmeyer flasks containing $150 \mathrm{~mL}$ of V8 medium (200 mL of V8 ${ }^{\circledR}$ Vegetable Juice, $800 \mathrm{~mL}$ of DW) supplemented with streptomycin sulfate $(50 \mu \mathrm{g} /$
$\mathrm{mL})$ and chloramphenicol $(75 \mu \mathrm{g} / \mathrm{mL})$. Isolates preserved under different methods were used. In this case, colonies were first grown in PDA, in the dark, for 7 days, then two plugs of mycelium (5 $\mathrm{mm}$ diameter) were transferred to V8 medium in flasks, incubating under agitation $(110 \mathrm{rpm})$ at $25^{\circ} \mathrm{C}$, in the dark. After 7 days, the mycelium was removed and ground using the Polytron ${ }^{\circledR}$ (System PT 1,200 C, Handheld Homogenizer), at 4,000 rpm, for $60 \mathrm{~s}$. Ten $\mathrm{mL}$ of the mycelial suspension was deposited in $15 \mathrm{~mL}$ of culture medium, which varied according to the experiment, in 9 $\mathrm{cm}$-diameter Petri plates. Three days after the beginning of the experiments, $10 \mathrm{~mL}$ of DW plus $0.01 \%$ Tween 80 was used to harvest the conidia with a brush (Foolad et al., 2000). The conidial suspension was collected in beakers; the conidial concentration was determined by counting the number of spores in a $10 \mu \mathrm{L}$-drop under the microscope (100X) and multiplying the number counted by 100 to estimate the total number of conidia $/ \mathrm{mL}$. The apparatus used to provide light during the incubation of the colonies had six light-bulbs spaced $5 \mathrm{~cm}$ apart and located $30 \mathrm{~cm}$ above the plates.

\section{Effects of culture medium dehydration and mycelium wounding on sporulation}

Five plates with $\mathrm{V} 8$ agar- $\mathrm{CaCO}_{3}$ medium $(200 \mathrm{~mL}$ of $\mathrm{V}^{\circledR}$ Vegetable Juice, $3 \mathrm{~g}$ of $\mathrm{CaCO}_{3}, 16 \mathrm{~g}$ of agar, 800 $\mathrm{mL}$ of $\mathrm{DW}$ ) per isolate/treatment were used. The V8 agar$\mathrm{CaCO}_{3}$ medium was chosen for the first experiment because it is a standard medium for A. solani sporulation. Three treatments were compared: plates sealed with Parafilm ${ }^{\circledR}$; plates without Parafilm ${ }^{\circledR}$; and open plates (without the lid). Light was provided by three black light bulbs (Sylvania ${ }^{\circledR}$ Luz Negra - 40W - 320-400 ๆm) and three fluorescent daylight bulbs (Sylvania ${ }^{\circledR}$ Luz do Dia - 40W) with $12 \mathrm{~h}$ photoperiod.

Two isolates (AS073 and AS074) were used in the experiment to quantify the effect of culture medium dehydration on sporulation. Each 20 plates/isolate was weighed before and after pouring the culture medium and mycelial suspension. Plates without lids were kept under black and daylight bulbs, as described above. Every $12 \mathrm{~h}$ the plates were weighed, until $84 \mathrm{~h}$ after the beginning of the experiment. All subsequent experiments used mycelium wounding and plates without lids, to allow for dehydration and fungal sporulation.

\section{Effects of the source of light, photoperiod, and culture medium on sporulation}

Three sources of light were compared: daylight bulbs, black light bulbs, and the combination black / daylight bulbs. In this last treatment, the bulbs were alternated. Each source was tested in a continuous light regime or in a 12 h photoperiod. Three plates with $\mathrm{V} 8$ agar- $\mathrm{CaCO}_{3}$ medium per isolate, per treatment (combination of light source and regime) were used. Plates kept under continuous darkness were used as controls. 
TABLE 1 - Characteristics of the isolates of Alternaria solani used to develop and/or to validate the protocol to induce sporulation

\begin{tabular}{|c|c|c|c|c|}
\hline Isolate & Host & Location & Year & Storage $^{(a)}$ \\
\hline AS04-001 & Potato & Carandaí $\mathrm{MG}$ & 2004 & $\mathrm{FP}$ \\
\hline AS073 & Tomato & Carandaí MG & 2004 & FP \\
\hline AS074 & Potato & Domingos Martins ES & 2004 & FP \\
\hline AS075 & Tomato & Viçosa MG & 2004 & $\mathrm{FP}$ \\
\hline AS076 & Potato & Bueno Brandão MG & 2004 & $\mathrm{FP}$ \\
\hline AS077 & Potato & Ibiá MG & 2004 & FP \\
\hline AS078 & Tomato & Venda Nova do Imigrante ES & 2004 & FP \\
\hline AS079 & Tomato & Planaltina GO & 2006 & FP \\
\hline AS082 & Tomato & Muniz Freire ES & 2000 & Castellani \\
\hline AS083 & Tomato & - & 1996 & Castellani \\
\hline AS088 & Potato & Ponta Grossa PR & 2000 & Castellani \\
\hline AS089 & Tomato & Ponta Grossa PR & 2000 & Castellani \\
\hline AS090 & Tomato & Capão Bonito SP & 2000 & Castellani \\
\hline AS091 & Tomato & Viçosa $\mathrm{MG}$ & 2000 & Castellani \\
\hline AS094 & Tomato & Coimbra $\mathrm{MG}$ & 2000 & Castellani \\
\hline AS095 & Tomato & Coimbra $\mathrm{MG}$ & 2000 & Castellani \\
\hline AS117 & Tomato & Valão do Barro RJ & 2000 & Castellani \\
\hline AS121 & Tomato & Itaperuna RJ & 2000 & Castellani \\
\hline AS123 & Tomato & Tocantins MG & 2000 & Castellani \\
\hline AS124 & Tomato & Tocantins MG & 2000 & Castellani \\
\hline AS130 & Tomato & Cajuri MG & 2000 & Castellani \\
\hline AS131 & Tomato & Cajuri $\mathrm{MG}$ & 2000 & Castellani \\
\hline AS132 & Tomato & Marília SP & 2000 & Castellani \\
\hline AS223 & Tomato & Castelo ES & 2005 & PDA \\
\hline AS250 & Potato & Conselheiro Lafaiete MG & 2005 & PDA \\
\hline AS259 & Potato & Cristalina GO & 2005 & PDA \\
\hline AS337 & Potato & Itapetininga $\mathrm{SP}$ & 2005 & PDA \\
\hline AS370 & Potato & Ipuiúna $\mathrm{MG}$ & 2006 & PDA \\
\hline CE20 & Tomato & - & 1999 & SG \\
\hline UFV22FF & Tomato & Viçosa MG & 2000 & PDA \\
\hline COIMBRA & Tomato & Coimbra $\mathrm{MG}$ & 2004 & PDA \\
\hline
\end{tabular}

(a) $\mathrm{FP}=$ filter paper $\left(-80^{\circ} \mathrm{C}\right), \mathrm{PDA}=$ tube with $\mathrm{PDA}\left(4^{\circ} \mathrm{C}\right)$, Castellani method (Dhingra \& Sinclair, 1995) and $\mathrm{SG}=$ silica gel

Four culture media, amended or not with $\mathrm{CaCO}_{3}$ were compared: PDA; V8 agar; Vegetable broth agar - VBA (Pereira et al., 2003) and Carrot agar-CA (20 g of carrot, 16 $\mathrm{g}$ of agar, $1 \mathrm{~L}$ of DW). The $\mathrm{pH}$ was adjusted to 7.5 and 6.5 in treatments with or without $\mathrm{CaCO}_{3}(3 \mathrm{~g} / \mathrm{L})$, respectively. Based on the results of the previous experiment, the plates were kept under black light, $12 \mathrm{~h}$ photoperiod. Three plates were used per isolate, per treatment.

\section{Effect of periodic subcultures on sporulation}

The isolates AS04/001, AS073, AS074, AS075, AS077 and AS078 were subcultured and at each transfer, sporulation was induced according to the protocol developed in the current study. The colonies were grown in PDA ( $\mathrm{pH}=6.5$ ) in the dark for 7 days. For subculturing two plugs of mycelium taken from the center of each colony to establish a new growth were transferred, one plug to a plate with PDA $(\mathrm{pH}=6.5)$ and one plug to a flask with $150 \mathrm{~mL}$ of $\mathrm{V} 8$ medium. Three plates and three flasks were prepared per isolate at each subculturing. Every 7 days, cultures in plates were subcultured. After colony development, the cultures in liquid medium were obtained and induced to sporulate using the best combination from the previous experiments. 


\section{Validation of the protocol to induce sporulation and infection}

Two experiments, the first with 20 isolates and the second with 30 isolates, were undertaken to validate the protocol. Conidial production was induced in five plates per isolate. Conidia of three randomly selected plates were harvested and a $10^{3}$ conidia $/ \mathrm{mL}$-suspension was used in germination and infectivity tests. To evaluate germination, $50 \mu \mathrm{L}$ of the conidial suspension from each isolate was deposited on one microscope slide. Three slides were prepared per isolate. In the first experiment, the slides were transferred to a plastic box $(11 \mathrm{~cm}$ length $\mathrm{x} 11 \mathrm{~cm}$ width $\mathrm{x}$ $4 \mathrm{~cm}$ height), kept at $25^{\circ} \mathrm{C}$, in the dark, for $12 \mathrm{~h}$, until the observation under the microscope (100X). In the second experiment, the incubation period was $6 \mathrm{~h}$. A conidium was considered as germinated when one germ tube was at least as long as the conidium's width. One hundred randomly selected conidia were examined per slide.

To assess the infectivity of the spores, 45 to 60 -dayold tomato plants cv. Santa Clara or detached leaflets of potato cv. Monalisa were inoculated. Detached leaflets of potato were used because the number of plants was not enough to conduct the experiment. Each tomato plant was divided into three thirds (upper, middle, and lower) based on plant height. In each third, three leaflets were tagged with a paper tag and a cover glass $(1 \times 1 \mathrm{~cm})$ was attached on the adaxial surface with double-faced adhesive tape. The conidial suspension was sprayed on the leaflets using a DeVilbiss 15 sprayer. The negative control was sprayed with water and the positive control was sprayed with the isolates AS078/AS079 and AS079, in experiments 1 and 2, respectively. For each isolate, three plants were inoculated and kept for $24 \mathrm{~h}$ in a moist chamber ( $100 \%$ relative humidity). Nine detached leaflets of potato were inoculated as above, and kept in a plastic box. After the inoculation, the cover glass was removed and placed upside down on top of a drop of lactophenol on a microscope slide. The number of conidia deposited on the cover glass was counted under the microscope (100X). The number of lesions formed in the leaflets was counted on the third and fourth day after inoculation. Based on the results of experiment 1, only leaflets of the middle third of tomato or potato plants were used in experiment 2. Six leaflets in each plant and four plants/isolate were inoculated.

The infection frequency (IF), considered as the ratio between the number of lesions $(\mathrm{L})$ and the number of conidia deposited on a leaflet, was used to assess infectivity. Leaflet area was measured on the fifth day after inoculation, using an electronic leaf area meter (Li-3.100 - Licor $\left.{ }^{\circledR}\right)$. The cover glass area $\left(1 \mathrm{~cm}^{2}\right)$ was subtracted from the total leaflet area to result in a corrected number of spores deposited on a given leaflet $(C N)$. The IF was determined as:

$$
I F(\%)=(L / C N) \times 100 .
$$

\section{Statistical analyses}

A two-way analysis of variance was conducted to analyze the data. Whenever the treatment $x$ isolate interaction term was significant, the analyses of the treatment effects were done by isolate. Each experiment was conducted twice (hereafter referred to as assays 1 and 2), except those for the quantification of culture medium dehydration, infection frequency, and subculturing. The Levene test was used to check the homogeneity of variance between assays conducted twice (Kuehl, 1994). Treatment means were compared using the Tukey test $(\alpha=0.05)$. In the experiment with culture media, the $\mathrm{pH}$ treatment effect was evaluated by contrasts. In all experiments, the sporulation data were transformed to $\log _{10}$ (number of conidia); when there was no sporulation in a treatment, the data were transformed to $\log _{10}$ (number of conidia +1 ). All analyses were done using the $\mathrm{SAS}^{\circledR}$ ver. 8.2.

\section{RESULTS}

\section{Effects of culture medium dehydration and mycelium wounding on sporulation}

Data from each assay were analyzed separately because of the lack of homocedasticity. Aerial mycelium growth with no sporulation was observed in colonies formed in plates with lids, sealed or not with Parafilm. In open plates, medium dehydration occurred and vegetative mycelia were sparse, and produced asexual structures. The sporulation varied among isolates, and ranged from $3.72 \times 10^{5}$ $\left(\mathrm{SE}=0.74 \times 10^{3}\right)$ to $11.46 \times 10^{5}\left(\mathrm{SE}=3.81 \times 10^{3}\right)$ conidia $/ \mathrm{mL}$ and from $2.79 \times 10^{5}\left(\mathrm{SE}=0.74 \times 10^{3}\right)$ to $5.99 \times 10^{5}\left(\mathrm{SE}=2.27 \times 10^{3}\right)$ conidia/mL, in assays 1 and 2 , respectively. The highest rate of culture medium dehydration (45\%) occurred in the first $12 \mathrm{~h}$. After $60 \mathrm{~h}$, no loss of moisture was observed until the last observation at $84 \mathrm{~h}$.

\section{Effects of the source of light, photoperiod, and culture medium on sporulation}

Data from both experiments were pooled and analyzed. Sporulation of all isolates was significantly $(\mathrm{P}<0.0001)$ affected by light source and photoperiod. Highest number of conidia was observed in colonies kept under black light $(\mathrm{P}<0.0001)$ and $12 \mathrm{~h}$ photoperiod (Figure 1). No isolates sporulated under continuous darkness. The data from the assays of culture media were analyzed separately. The interaction between culture medium (supplemented or not with $\mathrm{CaCO}_{3}$ ) $\mathrm{xpH}$ was significant in three of 16 interactions in assay 1 , and in 2 of 16 interactions in assay 2 (Table 2). Although a high number of conidia were produced in all media, either supplemented or not with $\mathrm{CaCO}_{3}$ (Table 3), PDA medium at $\mathrm{pH}=6.5$ was chosen for the subsequent experiments due to its lower cost.

\section{Effect of periodic subcultures on sporulation \\ Every colony sporulated until the $6^{\text {th }}$ subculture.} Different colonies of the same isolate did not differ 


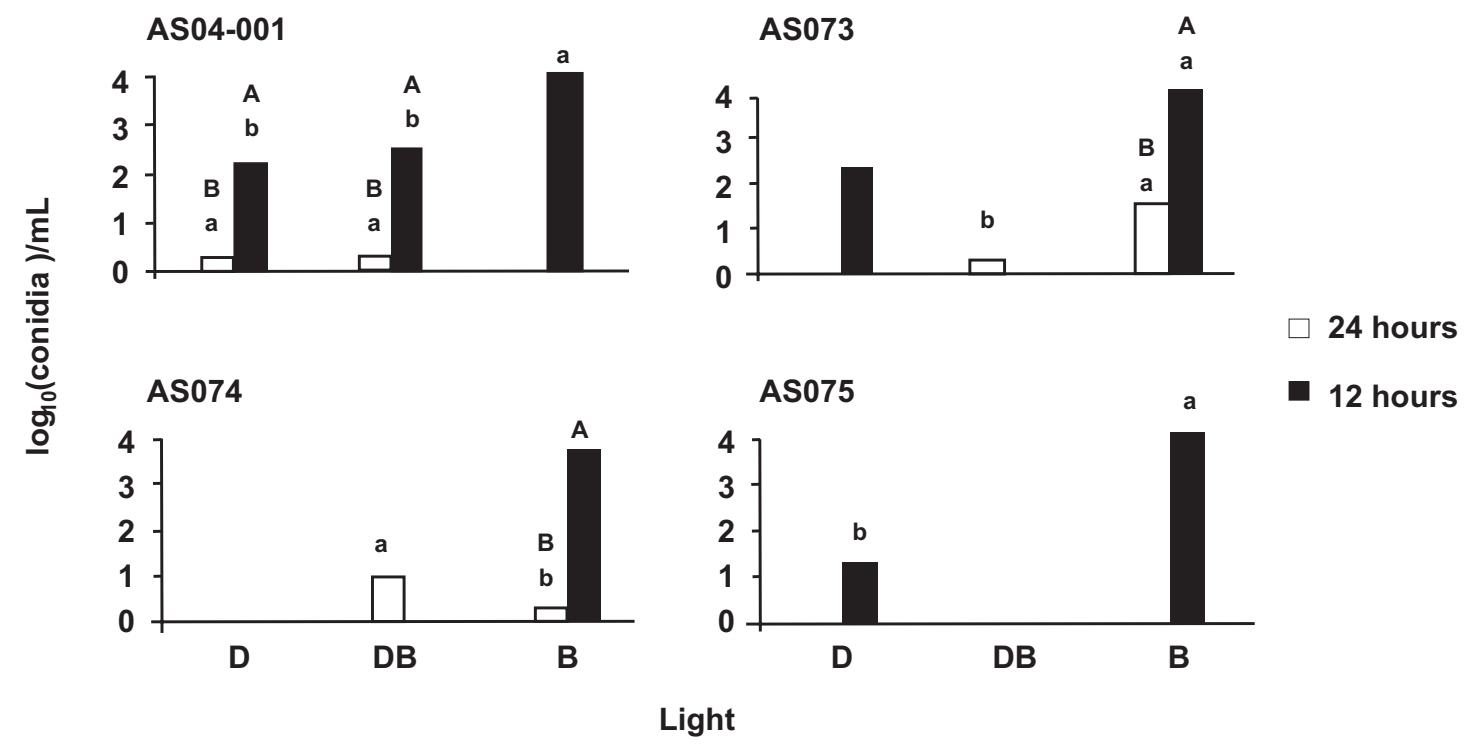

FIGURE 1 - Sporulation $\left[\log _{10}\right.$ (conidia) $\left./ \mathrm{mL}\right]$ of Alternaria solani in different sources of light $(\mathrm{D}=$ Daylight, $\mathrm{DB}=$ Daylight/Black, $B=$ Black) and photoperiod ( $24 \mathrm{~h}$ and $12 \mathrm{~h}$ ). For each isolate, bars with the same capital letter, for the same source of light, do not differ according to the Tukey test $(\alpha=0.05)$. Bars with the same small letter, for the same photoperiod, do not differ according to the Tukey test $(\alpha=0.05)$.

TABLE 2 - F values and, in parentheses, significance level, for differences between media of four isolates of Alternaria solani in different culture media supplemented $(\mathrm{pH}=7.5)$ or not $(\mathrm{pH}=6.5)$ with $\mathrm{CaCO}_{3}$, in two assays $(1$ and 2$)$

\begin{tabular}{|c|c|c|c|c|c|c|}
\hline \multirow{2}{*}{ Isolate } & \multirow{2}{*}{ Assay } & \multicolumn{5}{|c|}{ Culture medium } \\
\hline & & PDA & V8 agar & VBA & CA & All \\
\hline AS04-001 & 1 & $\begin{array}{c}12.58^{*} \\
(0.0027)\end{array}$ & $\begin{array}{c}1.16 \\
(0.2982)\end{array}$ & $\begin{array}{c}7.11 \\
(0.0169)\end{array}$ & $\begin{array}{c}0.01 \\
(0.9059)\end{array}$ & $\begin{array}{c}6.91 \\
(0.0182)\end{array}$ \\
\hline AS073 & $\begin{array}{l}2 \\
1\end{array}$ & $\begin{array}{c}53.60 \\
(<0.0001) \\
26.28 \\
(<0.0001)\end{array}$ & $\begin{array}{c}11.10 \\
(0.0042) \\
16.63 \\
(0.0009)\end{array}$ & $\begin{array}{c}4.84 \\
(0.0429) \\
10.64 \\
(0.0049)\end{array}$ & $\begin{array}{c}7.86 \\
(0.0127) \\
4.95 \\
(0.0409)\end{array}$ & $\begin{array}{c}31.68 \\
(<0.0001) \\
16.72 \\
(0.0009)\end{array}$ \\
\hline AS074 & $\begin{array}{l}2 \\
1\end{array}$ & $\begin{array}{c}17.21 \\
(0.0009) \\
0.67 \\
(0.4246)\end{array}$ & $\begin{array}{c}0.38 \\
(0.5443) \\
0.00 \\
(0.9628)\end{array}$ & $\begin{array}{c}1.12 \\
(0.3070) \\
1.60 \\
(0.2244)\end{array}$ & $\begin{array}{c}14.47 \\
(0.0017) \\
0.12 \\
(0.7297)\end{array}$ & $\begin{array}{c}12.85 \\
(0.0027) \\
0.71 \\
(0.4122)\end{array}$ \\
\hline AS075 & $\begin{array}{l}2 \\
1\end{array}$ & $\begin{array}{c}13.28 \\
(0.0022) \\
65.54 \\
(<0.0001)\end{array}$ & $\begin{array}{c}8.97 \\
(0.0086) \\
0.73 \\
(0.4064)\end{array}$ & $\begin{array}{c}0.03 \\
(0.8637) \\
6.77 \\
(0.0192)\end{array}$ & $\begin{array}{c}19.32 \\
(0.0005) \\
37.58 \\
(<0.0001)\end{array}$ & $\begin{array}{c}29.49 \\
(<0.0001) \\
29.00 \\
(<0.0001)\end{array}$ \\
\hline & 2 & $\begin{array}{c}67.43 \\
(<0.0001)\end{array}$ & $\begin{array}{c}10.13 \\
(0.0058)\end{array}$ & $\begin{array}{c}1.38 \\
(0.2570)\end{array}$ & $\begin{array}{c}14.77 \\
(0.0014)\end{array}$ & $\begin{array}{c}49.43 \\
(<0.0001)\end{array}$ \\
\hline
\end{tabular}

* Average from 3 replicates.

regarding sporulation. At least one colony of each isolate sporulated until the $9^{\text {th }}$ subculture. For AS077 and AS078, at least one colony produced conidia until the $18^{\text {th }}$ subculture and one colony of the isolate AS074 sporulated until the $20^{\text {th }}$ subculture (Figure 2).
Validation of the protocol to induce sporulation and infection

The following protocol was defined: colonies should be grown in $\mathrm{V} 8$ medium under agitation $(110 \mathrm{rpm})$, at $25^{\circ} \mathrm{C}$, in the dark, for 7 days. The harvested mycelia should be 
T.T.M.S. Rodrigues et al.

TABLE 3. Sporulation $\left[\log _{10}(\right.$ number of conidia +1$\left.) / \mathrm{mL}\right]$ of four isolates of Alternaria solani in different culture media supplemented $(\mathrm{pH}=7.5)$ or not $(\mathrm{pH}=6.5)$ with $\mathrm{CaCO}_{3}$, in two assays $(1$ and 2$)$

\begin{tabular}{|c|c|c|c|c|c|c|c|c|c|}
\hline & \multicolumn{9}{|c|}{ Culture Media } \\
\hline & \multirow[b]{2}{*}{ pH } & \multicolumn{2}{|c|}{ PDA } & \multicolumn{2}{|c|}{ V8 } & \multicolumn{2}{|c|}{ VBA } & \multicolumn{2}{|c|}{$\mathbf{C A}$} \\
\hline & & $1^{* 3}$ & 2 & 1 & 2 & 1 & 2 & 1 & 2 \\
\hline \multirow[t]{2}{*}{ AS04/001 } & 6,5 & $\begin{array}{c}5,04^{* 4} \\
A^{*} \mathrm{a}\end{array}$ & $\begin{array}{l}5,10 \\
\mathrm{~A} \mathrm{a}^{* *}\end{array}$ & $\begin{array}{l}4,49 \\
\mathrm{~A} a b\end{array}$ & $\begin{array}{l}4,87 \\
\mathrm{Ab}\end{array}$ & $\begin{array}{l}4,43 \\
\mathrm{Ab}\end{array}$ & $\begin{array}{r}4,64 \\
\text { A c }\end{array}$ & $\begin{array}{r}4,35 \\
\mathrm{Ab}\end{array}$ & $\begin{array}{r}4,63 \\
\text { A c }\end{array}$ \\
\hline & 7,5 & $\begin{array}{c}4,42 \\
\mathrm{~B} \text { a }\end{array}$ & $\begin{array}{c}4,71 \\
\mathrm{~B} \mathrm{a}\end{array}$ & $\begin{array}{l}4,68 \\
\mathrm{~A} \mathrm{a}\end{array}$ & $\begin{array}{l}4,70 \\
\mathrm{~A} \mathrm{a}\end{array}$ & $\begin{array}{l}3,96 \\
\mathrm{Ab}\end{array}$ & $\begin{array}{c}4,76 \\
\text { A a }\end{array}$ & $\begin{array}{l}4,32 \\
\mathrm{~A} \mathrm{ab}\end{array}$ & $\begin{array}{r}4,49 \\
\mathrm{Ab}\end{array}$ \\
\hline \multirow[t]{2}{*}{ AS073 } & 6,5 & $\mathrm{Aa}^{4,98}$ & $\begin{array}{c}5,10 \\
\mathrm{~A} \mathrm{a}\end{array}$ & $\begin{array}{l}\quad 4,73 \\
\mathrm{~A} \mathrm{ab}\end{array}$ & $\begin{array}{c}4,89 \\
\mathrm{~A} \mathrm{a}\end{array}$ & $\begin{array}{c}4,24 \\
\mathrm{Ab}\end{array}$ & $\begin{array}{r}4,98 \\
\text { A a }\end{array}$ & $\begin{array}{r}4,27 \\
\mathrm{Ab}\end{array}$ & $\begin{array}{r}4,80 \\
\mathrm{~A} \mathrm{a}\end{array}$ \\
\hline & 7,5 & $\begin{array}{l}4,26 \\
\mathrm{~B} \mathrm{ab}\end{array}$ & $\begin{array}{l}4,68 \\
\text { B b }\end{array}$ & $\begin{array}{l}4,15 \\
\mathrm{~B} \mathrm{~b}\end{array}$ & $\begin{array}{l}4,82 \\
\mathrm{~A} a b\end{array}$ & $\begin{array}{l}4,70 \\
\mathrm{~A} \mathrm{a}\end{array}$ & $\begin{array}{c}5,10 \\
\mathrm{~A} \mathrm{a}\end{array}$ & $\begin{array}{c}3,96 \\
\mathrm{Ab}\end{array}$ & $\begin{array}{c}4,42 \\
\text { B b }\end{array}$ \\
\hline \multirow[t]{2}{*}{ AS074 } & 6,5 & $\begin{array}{r}4,57 \\
\mathrm{~A} \mathrm{a}\end{array}$ & $\begin{array}{l}4,48 \\
\mathrm{~A} \mathrm{ab}\end{array}$ & $\begin{array}{l}2,85 \\
\mathrm{Ab}\end{array}$ & $\begin{array}{l}4,73 \\
\mathrm{~A} \mathrm{a}\end{array}$ & $\begin{array}{l}2,77 \\
\mathrm{Ab}\end{array}$ & $\begin{array}{c}4,58 \\
\text { A a }\end{array}$ & $\begin{array}{c}2,99 \\
\mathrm{~A} \mathrm{~b}\end{array}$ & $\begin{array}{r}4,05 \\
\mathrm{Ab}\end{array}$ \\
\hline & 7,5 & $\begin{array}{c}4,31 \\
\mathrm{~B} \mathrm{a}\end{array}$ & $\begin{array}{l}3,98 \\
\mathrm{~B} \mathrm{~b}\end{array}$ & $\begin{array}{l}2,87 \\
\mathrm{Ab}\end{array}$ & $\begin{array}{l}4,32 \\
\mathrm{~A} a b\end{array}$ & $\begin{array}{l}2,36 \\
\mathrm{Ab}\end{array}$ & $\begin{array}{r}4,60 \\
\text { A a }\end{array}$ & $\begin{array}{c}3,11 \\
\mathrm{Ab}\end{array}$ & $\begin{array}{c}3,44 \\
\text { B c }\end{array}$ \\
\hline \multirow[t]{2}{*}{ AS075 } & 6,5 & $\begin{array}{c}5,24 \\
\mathrm{~A} \mathrm{a}\end{array}$ & $\begin{array}{r}5,13 \\
\mathrm{~A} \mathrm{a}\end{array}$ & $\begin{array}{l}4,48 \\
\mathrm{Ab}\end{array}$ & $\begin{array}{l}4,58 \\
\mathrm{Ab}\end{array}$ & $\begin{array}{l}4,49 \\
\mathrm{Ab}\end{array}$ & $\begin{array}{c}3,94 \\
\text { A c }\end{array}$ & $\begin{array}{r}4,77 \\
\mathrm{Ab}\end{array}$ & $\begin{array}{r}4,30 \\
\mathrm{Ab}\end{array}$ \\
\hline & 7,5 & $\begin{array}{l}3,92 \\
\mathrm{~B} \mathrm{~b}\end{array}$ & $\begin{array}{c}4,40 \\
\mathrm{~B} \mathrm{a}\end{array}$ & $\begin{array}{l}4,62 \\
\mathrm{~A} \mathrm{a}\end{array}$ & $\begin{array}{l}4,30 \\
\mathrm{Ab}\end{array}$ & $\begin{array}{l}4,91 \\
\mathrm{~A} \mathrm{a}\end{array}$ & $\begin{array}{r}4,04 \\
\mathrm{Ab}\end{array}$ & $\begin{array}{c}3,77 \\
\mathrm{~B} \mathrm{~b}\end{array}$ & $\begin{array}{c}3,96 \\
\mathrm{~B} \mathrm{~b}\end{array}$ \\
\hline
\end{tabular}

* For the same isolate, culture medium and assay, averages followed by the same capital letter do not differ according to the Tukey test $(\alpha=0.05)$.

** For the same isolate, $\mathrm{pH}$ and assay, averages followed by the same small letter do not differ according to the Tukey test ( $\alpha=$ $0.05)$.

${ }^{* 3}$ Assays 1 and 2.

${ }^{*}$ Sporulation $=\log _{10}($ number of conidia +1$) / \mathrm{mL}$. Average from 3 replicates.

ground using Polytron ${ }^{\circledR}$, at $4000 \mathrm{rpm}$, for $1 \mathrm{~min}$, and $10 \mathrm{~mL}$ of the mycelial suspension transferred to plates with PDA $(\mathrm{pH}=6.5)$. The plates should be kept without lids, under six light-bulbs of black light spaced $5 \mathrm{~cm}$ apart and placed 30 $\mathrm{cm}$ above the plates; $12 \mathrm{~h}$ photoperiod, at $25^{\circ} \mathrm{C}$, for $60 \mathrm{~h}$.

In experiment 1 , all isolates sporulated, and the minimum germination rate was $96 \%$. All isolates were pathogenic to their original host species, but the infection frequency varied. Greater infection frequency occurred with isolates from potato. For most isolates, the highest and lowest values obtained from the middle and upper third of the plants, respectively (Table 4). In experiment 2, 23 out of 30 isolates sporulated, because seven isolates did not grow in liquid medium. In general, the germination rates in experiment 2 were lower than in experiment 1 . The methodology used in experiment 2 allowed better observation of the germinated conidia and more accurate counting. In experiment 2 only the middle third of the plants were inoculated and all isolates were pathogenic to their original hosts (Table 5).

\section{DISCUSSION}

The adapted and validated protocol allowed efficient induction of sporulation of A. solani, in vitro.
Profuse mycelial growth without the production of conidia is commonly observed in vitro conditions. In general, vegetative growth requires different conditions from sporulation (Dhingra \& Sinclair, 1995). In vivo, conidiophores are formed under high humidity and light, whereas conidial formation is favored by alternating high-low humidity with darkness (Waggoner \& Horsfall, 1969). Simulating the in vivo conditions that favor sporulation under controlled conditions has not been successful in previous attempts to develop a protocol to induce sporulation in A. solani. Other factors, besides light conditions and levels of humidity may be required to stimulate conidial formation in colonies developed in vitro.

The dehydration rate and aeration of the mycelia affected sporulation of $A$. solani in vitro. Initially, plates without lid had high humidity, but after $12 \mathrm{~h}$, there was a $10 \%$ decrease of the initial mycelium mass and conidiophores were formed under dehydration conditions. Mycelial dehydration may trigger the initial stimulus for sporulation. However, the mechanism involved in this process in $A$. solani is unknown. It was reported that conidiophores in contact with a film of water may revert to vegetative hyphae and halt conidiogenesis (Aragaki et al., 1973). In Neurospora crassa, genes associated 


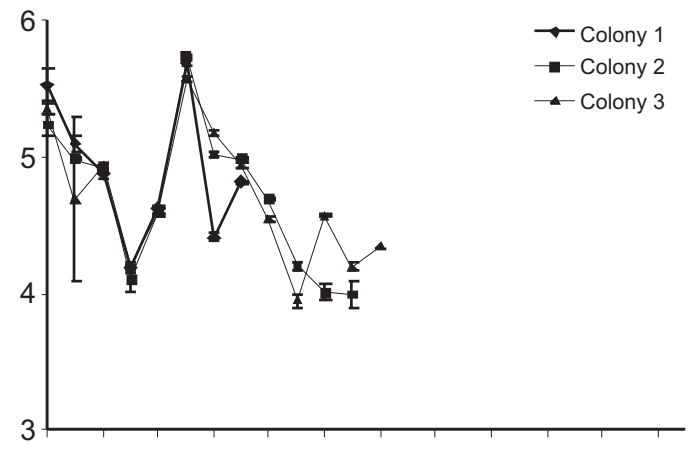

AS074

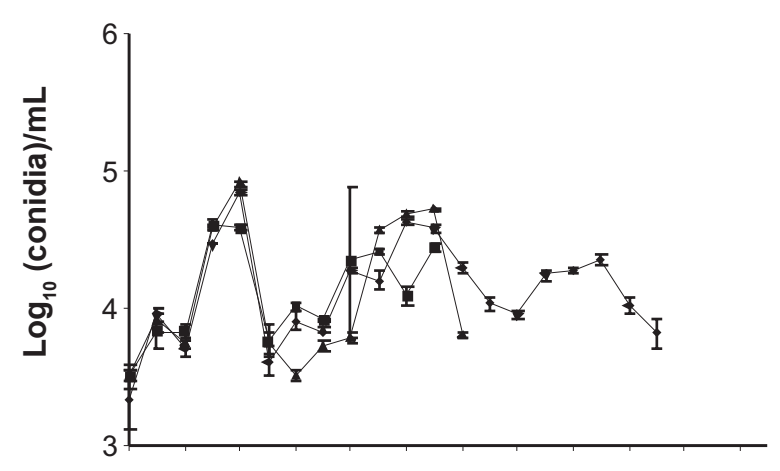

AS077

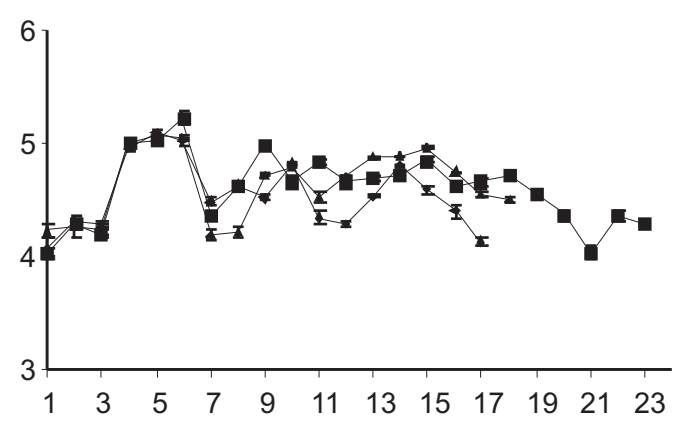

Subculture

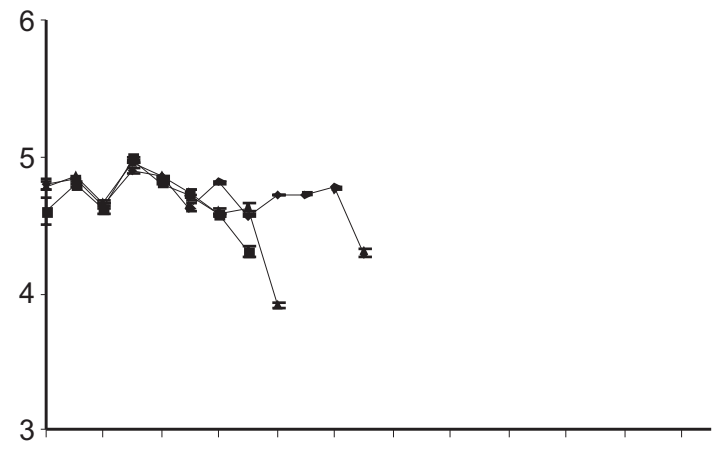

AS075

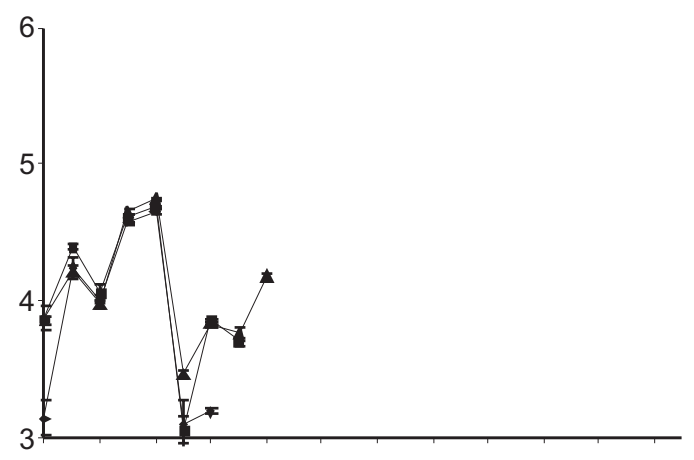

AS078

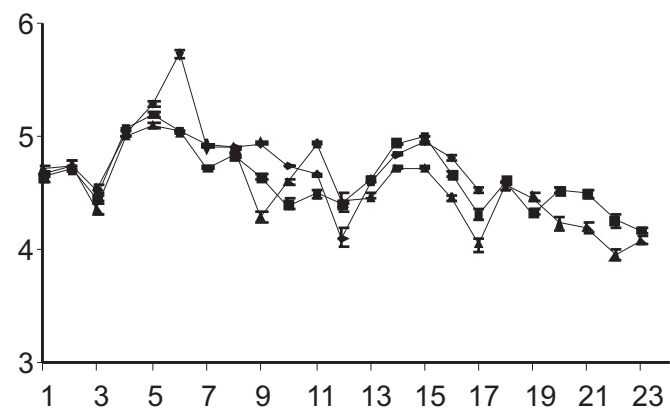

Subculture

FIGURE 2 - Sporulation $\left[\log _{10}\right.$ (conidia)/mL] of six isolates of Alternaria solani during 24 periodic subcultures. Colonies 1 , 2 and 3 are replicates of each isolate. Bars represent standard deviation.

with conidiogenesis were translated only when colony desiccation occurred (Changgong et al., 1997). In the current work, the treatments that did not cause moisture loss promoted mycelial growth and no sporulation. Associated with dehydration, greater aeration of the colonies may also have contributed to pathogen sporulation. Low accumulation of carbon dioxide as well as higher oxygen availability seems to favor sporulation of $A$. solani (Lukens \& Horsfall, 1973). The pathogen is more sensitive to the increase of carbon dioxide and the decrease of oxygen during the reproductive rather than the vegetative growth phase (Lukens \& Horsfall, 1973).
Humidity, $\mathrm{CO}_{2}$, and oxygen levels affect the sporulation of A. solani, but how these factors act on the physiology of the sporulation remains to be elucidated.

The protocol used in the present study also resulted in satisfactory sporulation of other species of Alternaria (Walker, 1980, 1982; Ávila et al., 2000, Vieira, 2004). Moreover, it can also be used to induce sporulation in Colletotrichum graminicola, C. malvarum, Drechslera sorghicola, Helminthosporium spp. and Curvularia spp. (Walker, 1980). This protocol is effective for production of massive amounts of inoculum when strict aseptic conditions are not required (Walker, 1980). 
T.T.M.S. Rodrigues et al.

TABLE 4 - Sporulation, percent of conidial germination and infection frequency of 20 isolates of Alternaria solani in tomato and potato. Experiment 1, to validate the protocol

\begin{tabular}{|c|c|c|c|c|c|}
\hline \multirow[b]{2}{*}{ Isolate } & \multirow{2}{*}{ Sporulation $^{(a)}$} & \multirow{2}{*}{ Germination $^{(b)}$} & \multicolumn{3}{|c|}{ Infection frequency } \\
\hline & & & Upper third & Middle third & Lower third \\
\hline AS04/001 & $8.8(0.34)$ & $97(0.67)$ & $0.30^{(\mathbf{d})}(0.18)$ & $13.12(2.30)$ & $9.26(3.45)$ \\
\hline AS073 & $10.5(0.91)$ & $98(0.33)$ & $0.35(0.11)$ & $1.06(0.42)$ & $0.17(0.06)$ \\
\hline AS074 & $3.1(0.16)$ & $96(0.88)$ & $0.10(0.05)$ & $3.19(0.47)$ & $6.40(2.64)$ \\
\hline AS075 & $10.4(0.53)$ & $98(0.00)$ & $0.11(0.07)$ & $0.19(0.08)$ & $0.07(0.04)$ \\
\hline AS076 & $21.0(1.20)$ & $99(0.58)$ & $2.21(0.54)$ & $2.47(0.57)$ & $2.27(0.38)$ \\
\hline AS077 & $6.3(0.17)$ & $86(2.33)$ & $4.30(1.24)$ & $7.84(3.35)$ & $5.77(2.32)$ \\
\hline AS078 & $20.2(1.35)$ & $99(0.33)$ & $0.04(0.02)$ & $0.23(0.06)$ & $0.13(0.04)$ \\
\hline AS079 & $53.6(0.30)$ & $96(0.58)$ & $5.52(2.33)$ & $2.84(0.69)$ & $1.75(0.42)$ \\
\hline AS088 & $5.34(0.34)$ & $99(0.67)$ & $10.08(5.54)$ & $2.01(0.36)$ & $2.92(0.70)$ \\
\hline AS089 & $2.1(0.15)$ & $97(1.20)$ & $0.13(0.08)$ & $0.42(0.20)$ & $0.05(0.02)$ \\
\hline $\mathrm{AS} 124$ & $13.9(0.55)$ & $99(0.33)$ & $1.35(0.22)$ & $2.72(0.54)$ & $1.23(0.42)$ \\
\hline AS131 & $10.2(0.39)$ & $90(0.58)$ & $0.04(0.02)$ & $0.00(0.00)$ & $0.03(0.01)$ \\
\hline AS132 & $13.48(1.00)$ & $96(1.20)$ & $0.16(0.06)$ & $0.48(0.25)$ & $0.56(0.16)$ \\
\hline AS091 & $2.3(0.06)$ & $96(0.00)$ & $0.18(0.03)$ & $0.29(0.12)$ & $0.25(0.15)$ \\
\hline AS095 & $6.6(0.23)$ & $99(0.00)$ & $0.18(0.05)$ & $0.10(0.07)$ & $0.12(0.08)$ \\
\hline AS121 & $10.84(0.49)$ & $99(0.33)$ & $0.05(0.02)$ & $0.04(0.01)$ & $0.12(0.08)$ \\
\hline AS123 & $6.44(0.19)$ & $98(0.58)$ & $0.55(0.27)$ & $0.55(0.15)$ & $0.14(0.05)$ \\
\hline CE 20 & $8.26(0.48)$ & $92(0.33)$ & $0.26(0.11)$ & $0.10(0.04)$ & $0.07(0.02)$ \\
\hline UFV $22 \mathrm{FF}$ & $12.48(1.42)$ & $98(0.58)$ & $0.02(0.01)$ & $0.05(0.02)$ & $0.03(0.01)$ \\
\hline COIMBRA & $31.58(1.21)$ & $98(0.33)$ & $0.05(0.03)$ & $0.28(0.08)$ & $0.16(0.11)$ \\
\hline \multicolumn{6}{|l|}{ Control*- 1} \\
\hline AS078 & $11.04(0.34)$ & $98(0.33)$ & $0.03(0.02)$ & $0.09(0.02)$ & $0.07(0.01)$ \\
\hline \multicolumn{6}{|l|}{ Control- 1} \\
\hline AS079 & $6.84(0.15)$ & $98(0.88)$ & $3.54(0.79)$ & $3.18(0.63)$ & $1.44(0.32)$ \\
\hline \multicolumn{6}{|l|}{ Control- 2} \\
\hline AS078 & $9.94(0.34)$ & $98(0.33)$ & $0.02(0.01)$ & $0.07(0.01)$ & $0.07(0.03)$ \\
\hline \multicolumn{6}{|l|}{ Control- 2} \\
\hline AS079 & $7.44(0.19)$ & $98(0.33)$ & $0.07(0.02)$ & $0.29(0.06)$ & $0.20(0.06)$ \\
\hline
\end{tabular}

(a) Average of 5 values (conidia $\times 10^{4} / \mathrm{mL}$ of distilled water), number in parentheses is the standard error x $10^{4}$; (b) average of 3 replicates; ${ }^{(c)}$ [(number of lesions/ number of conidia in each leaflet) x 100], the isolates were inoculated on their original host, and ${ }^{\text {(d) }}$ average of 9 replicates $(\%)$.

* Control 1 and 2 = isolates used as positive control.

Both the quality and the amount of light are critical for sporulation of $A$. solani (Leach, 1962; Douglas, 1972). In the present work, greater sporulation was obtained under alternated regime of light ( $12 \mathrm{~h}$ photoperiod). This alternation simulates conditions required for conidial formation, as conidiophore formation occurs under irradiation and conidium formation during the dark period (Lukens, 1960; Leach, 1967; Waggoner \& Horsfall, 1969; Douglas, 1972; Walker, 1980). Wavelengths near 310 ๆm, provided by black light, stimulate sporulation of $A$. solani and the conidiophores do not revert to vegetative hyphae when exposed to the dark, allowing conidial formation (Aragaki et al., 1973). Some authors have speculated that photoreceptor pigments could be involved in inducing or inhibiting sporulation by certain wavelengths (Leach, 1965; Trione \& Leach, 1966; Honda \& Nemoto, 1984). A compound called P310 ("Photoreceptor" 310) was obtained from sporulating colonies of $A$. chrysanthemi grown under black light, but not from non-sporulating colonies grown in the dark (Leach, 1965). The authors postulated that this compound could also play a role in sporulation of $A$. dauci (Trione \& Leach, 1966). The chemical structure and the function of P310 have not yet been determined.
In A. solani, the production of conidiophores has nutritional requirements distinct from the production of conidia. The fungus requires a source of carbon (sugar) to produce high quantity of conidiophores, but high availability of sugar inhibits the production of conidia (Waggoner \& Horsfall, 1969). This fact was observed in the present study when sucrose was added to the V8 liquid medium: the fungus grew abundantly, but produced only conidiophores (data not shown). After the pioneering work of Miller (1955), $\mathrm{CaCO}_{3}$ has been added to various culture media, in different protocols, but the results vary according to the medium tested. In this work, as in Vieira's (2004), sporulation was higher when VBA was supplemented with $\mathrm{CaCO}_{3}$, although there were no significant differences from the medium without $\mathrm{CaCO}_{3}$. However, sporulation was lower in PDA supplemented with $\mathrm{CaCO}_{3}$, a fact that has been observed previously on $A$. solani (Moretto \& Barreto, 1995). Despite the evidence that the addition of $\mathrm{CaCO}_{3}$ increases sporulation, it is not clear whether the effect is due to the change in $\mathrm{pH}$, or the supplementation of calcium.

Periodical subculturing, commonly used with fungi, can affect sporulation and pathogenicity of fungal plant pathogens (Dhingra \& Sinclair, 1995). In A. solani, 
TABLE 5 - Sporulation, germination and infection frequency (number of lesions/ number of conidia in each leaflet) $\mathrm{x}$ 100, of 23 isolates of Alternaria solani. Experiment 2, to validate the protocol

\begin{tabular}{|c|c|c|c|}
\hline Isolate & Sporulation $^{(\mathbf{a})}$ & Germination $^{(b)}$ & Infection frequency $^{(\mathrm{c})}$ \\
\hline AS078 & $0.72(0.07)$ & $82(3.52)$ & $0.40(0.16)$ \\
\hline AS082 & $2.10(0.21)$ & $68(1.20)$ & $0.17(0.06)$ \\
\hline AS083 & $33.11(1.25)$ & $79(1.20)$ & $0.20(0.05)$ \\
\hline AS084 & $0.74(0.05)$ & $87(1.20)$ & $0.44(0.08)$ \\
\hline AS088 & $3.20(0.16)$ & $92(0.88)$ & $0.45(0.05)$ \\
\hline AS089 & $2.78(0.13)$ & $80(1.20)$ & $0.18(0.02)$ \\
\hline AS090 & $0.76(0.05)$ & $69(0.58)$ & $0.75(0.39)$ \\
\hline AS091 & $0.70(0.07)$ & $74(0.88)$ & $0.17(0.02)$ \\
\hline AS094 & $3.79(0.15)$ & $79(3.18)$ & $0.19(0.04)$ \\
\hline AS095 & $12.88(0.44)$ & $93(1.16)$ & $1.17(0.15)$ \\
\hline AS117 & $4.38(0.17)$ & $74(2.03)$ & $0.06(0.02)$ \\
\hline AS121 & $1.42(0.09)$ & $82(0.88)$ & $0.67(0.08)$ \\
\hline AS123 & $1.12(0.086)$ & $74(1.86)$ & $0.31(0.05)$ \\
\hline AS124 & $0.84(0.051)$ & $76(2.52)$ & $1.02(0.18)$ \\
\hline AS130 & $3.06(0.09)$ & $90(0.88)$ & $0.52(0.12)$ \\
\hline AS131 & $1.40(0.11)$ & $72(0.88)$ & $0.77(0.12)$ \\
\hline AS132 & $2.40(0.16)$ & $90(1.20)$ & $0.59(0.1)$ \\
\hline AS223 & $1.16(0.12)$ & $87(1.20)$ & $0.21(0.05)$ \\
\hline AS250 & $7.74(0.14)$ & $87(2.52)$ & $0.28(0.03)$ \\
\hline AS259 & $3.82(0.12)$ & $89(1.77)$ & $0.25(0.03)$ \\
\hline AS337 & $2.04(0.09)$ & $89(4.71)$ & $0.26(0.03)$ \\
\hline AS370 & $2.32(0.13)$ & $82(1.77)$ & $0.51(0.07)$ \\
\hline Control*- 1 AS079 & $5.62(0.15)$ & $89(2.19)$ & $1.08(0.14)$ \\
\hline Control- 2 AS079 & $6.22(0.14)$ & $89(0.58)$ & $0.30(0.04)$ \\
\hline Control- 3 AS079 & $10.56(0.56)$ & $88(2.08)$ & $0.57(0.09)$ \\
\hline Control- 4 AS079 & $1.20(0.11)$ & $83(1.53)$ & $0.15(0.05)$ \\
\hline Control- 5 AS079 & $3.04(0.16)$ & $85(1.86)$ & $0.49(0.08)$ \\
\hline
\end{tabular}

(a) Average of 9 values (conidia $\times 10^{4} / \mathrm{mL}$ of distilled water), number in parentheses represents the standard error $\mathrm{x} 10^{4}$; (b) average of 3 values $(\%)$; ${ }^{(c)}$ average of 24 values $(\%)$.

* Control 1 to 5 = isolate used as positive control.

periodical subculturing affects sporulation (Rotem, 1994). In the present study, the way the fungus was subcultured allowed for all isolates to sporulate for at least six subcultures. In another study, after two or three successive subcultures, the isolates of $A$. solani no longer sporulated (Padhi \& Rath, 1973). According to the authors, the isolates that sporulated longer were mutants that emerged in culture after fungal isolation.

The production of a good quantity of quality inoculum is crucial for studying many aspects of fungal species. The evaluated protocol resulted in proper amounts and quality of sporulation of $A$. solani. The high rate of germination found in experiment 1 cannot reflect reality. Due to the long incubation time $(12 \mathrm{~h})$, the germ tubes with multiple cells formed a net of mycelia and identifying individual conidia was difficult. In experiment 2, germination rates were lower than in experiment 1 , but the methodology allowed better evaluation of germination. Furthermore, conidia were infective to tomato and potato leaflets. Differences in the inoculated material, whether detached leaflets or not, may have influenced the rates of infection frequency. Changes in the physiology of the detached leaflets may have resulted in greater susceptibility, therefore leading to high values of infection frequency being observed for potato isolates. Moreover, A. solani has great pathogenic variability, which may be the main cause of the variations of the infection frequencies (Rotem, 1994). Despite the variations, all isolates were infective and the protocol developed was appropriate to induce sporulation of $A$. solani in vitro. 


\section{ACKNOWLEDGMENTS}

The authors are grateful to Fundação de Amparo à Pesquisa do Estado de Minas Gerais - FAPEMIG for partially funding this research. LAM and ESGM acknowledge their research fellowships from CNPq.

\section{REFERENCES}

Aragaki M, Nishimoto KM, Hylin JW (1973) Vegetative reversion of conidiophores in Alternaria tomato. Mycologia 65:1205-1210.

Ávila ZR, Mello SCM, Ribeiro ZMA, Fontes EMG (2000) Produção de inóculo de Alternaria cassiae. Pesquisa Agropecuária Brasileira 35:533-541.

Changgong L, Matthew SS, Schmidhauser TJ (1997) Developmental and photoregulation of three Neurospora crassa caratenogenic genes during conidiation induced by dessication. Fungal Genetics and Biology 21:101-108.

Dalla Pria M, Bergamin Filho A, Amorim L (1997) Avaliação de diferentes meios de cultura na esporulação de Colletotrichum lindemuthianum, Phaeoisariopsis griseola e Alternaria sp. Summa Phytopathologica 23:181-183.

Dhingra OD, Sinclair JB (1995) Basic Plant Pathology Methods. 2nd ed. Boca Raton FL. CRC Press.

Douglas DR (1972) The effect of light and temperature on the sporulation of different isolates of Alternaria solani. Canadian Journal of Botany 50:629-634.

Foolad MR, Ntahimpera N, Christ BJ, Lin GY (2000) Comparasion of field, greenhouse, and detached-leaflet evaluations of tomato germ plasm for early bligth resistance. Plant Disease 84:967-972.

Fourtouni A, Manetas Y, Christias C (1998) Effect of UV-B radiation on growth, pigmentation, and spore production in the phytopathogenic fungus Alternaria solani. Canadian Journal of Botany 76:2093-2099.

Honda Y, Nemoto M (1984) An action spectrum for photoinhibition of conidium formation in the fungus Alternaria solani. Canadian Journal of Botany 62:2865-2871.

Idnurm A, Heitman J (2005) Light controls growth and development via a conserved pathway in the fungal Kingdom. PLoS Biol 3:615-626.

Kuehl RO (1994) Statistical principles of research design and analysis. Belmont. Duxbury Press.

Leach CM (1962) Sporulation of diverse species of fungi under near-ultraviolet radiations. Canadian Journal of Botany 40:151161.

Leach CM (1965) Ultraviolet absorbing substances associated with ligth induced sporulation in fungi. Canadian Journal of Botany 43:185-200.
Leach CM (1967) Interaction of near-ultaviolet light and temperature on sporulation of the fungi Alternaria, Cercosporella, Fusarium, Helminthosporium, and Stemphylium. Canadian Journal of Botany 45:1999-2016.

Lukens RJ (1960) Conidial production from filter paper culture of Helminthosporium vagans and Alternaria solani. Phytopathology 50:867-868.

Lukens RJ, Horsfall JG (1973) Processes of sporulation in Alternaria solani and their response to metabolic inhibitors. Phytopathology 63:176-182.

Miller PM (1955) V-8 juice agar as a general purpose medium for fungi and bacteria. Phytopathology 45:461-462.

Moretto KCK, Barreto M (1995) Efeito de alguns meios de cultura no crescimento e na esporulação de Alternaria solani e de alguns fatores na freqüência de infecção em tomateiro. Summa Phytopathologica 21:188-191.

Padhi NN, Rath GC (1973) Sporulation of Alternaria solani in pure culture. Indian Phytopathology 26:495-501.

Pereira JM, Barreto RW, Ellison CA, Maffia LA(2003) Corynespora cassiicola f. sp. lantanae: a potencial biocontrol agent from Brazil for Lantana camara. Biological Control 26:21-31.

Pitelli RLCM, Amorim L (2003) Effects of different dew periods and temperatures on infection of Senna obtusifolia by a Brazilian isolate of Alternaria cassiae. Biological Control 28:237-242.

Purschwitza J, Müllera S, Kastnera C, Fischera R (2006) Seeing the rainbow: light sensing in fungi. Current Opinion in Microbiology 9:566-571.

Rotem J (1994) The genus Alternaria: biology, epidemiology and pathogenicity. Saint Paul MN. APS Press.

Rotem J, Bashi E (1969) Induction of sporulation of Alternaria porri f. sp. solani by inhibition of its vegetative development. Transactions of the British Mycological Society 53:433-439.

Shahin EA, Shepard JF (1979) An efficient technique for inducing profuse sporulation of Alternaria species. Phytopathology 69:618620.

Trione EJ, Leach CM (1966) Sporogenic substance isolated from fungi. Nature 212:163-164.

Vieira BS (2004) Alternaria euphorbiicola como micoherbicida para leiteiro (Euphorbia heterophylla): produção massal e integração com herbicidas químicos. Tese de Doutorado. Viçosa MG. Universidade Federal de Viçosa.

Waggoner PE, Horsfall JG (1969) EPIDEM. A simulator of plant disease written for a computer. Bulletin of the Connecticut Agricultural Experiment Station, New Haven 698:1-80.

Walker HL (1980) Alternaria macrospora as a potencial biocontrol agent for Spurred anoda. Production of spores for field studies. U. S. Department of Agriculture. Science and Education Administration. Advances in Agricultural Technology AAT-S-12:1-5.

Walker HL (1982) Seedling blight of sicklepod caused by Alternaria cassiae. Plant Disease 66:426-428. 